\title{
Uma oficina de talha na Sé de Mariana o fazer artístico e o contrato de trabalho*
}

\section{A carving atelier at the Cathedral of Mariana the artistic work and the employment contract}

\author{
AZIZ JOSÉ DE OLIVEIRA PEDROSA** \\ Escola de Arquitetura \\ Universidade Federal de Minas Gerais \\ Belo Horizonte (MG) \\ Brasil
}

\begin{abstract}
RESUMO Os modos pelos quais se organizavam as oficinas de talha ainda são pouco conhecidos pela historiografia da arte mineira setecentista. Isso ocorre, entre outros fatores, pela escassez de fontes primárias que forneçam tais informações. Nesse sentido, o presente artigo demonstra algumas peculiaridades da formação e gestão de uma oficina de talha instalada no interior da Matriz de Nossa Senhora da Conceição, atual Sé de Mariana. Buscou-se também, ressaltar a importância do contrato de arrematação da obra de talha, no tocante ao cumprimento de suas cláusulas contratuais. Tal estudo foi subsidiado em documentação primária que relata a composição e organização de uma oficina de talha que, por volta do ano de 1749, sofre sanções penais por descumprimento dos prazos e condições previamente estabelecidas no contrato de arrematação da obra.
\end{abstract}

Palavras-chave arte, ofício, contrato

* Artigo recebido em: 02/08/2012. Aprovado em: 07/02/2013.

** Doutorando em Arquitetura e Urbanismo pela UFMG, Mestre em Arquitetura e Urbanismo pela UFMG. Contato: azizpedrosa@yahoo.com.br 
ABSTRACT The ways in which carving ateliers were organized are still unknown by Minas Gerais art historiography in the $18^{\text {th }}$ century. This fact is due, besides other reasons, to the scarcity of primary sources that can provide further information about it. Therefore, this article shows some peculiarities of the creation and management of a carving atelier that was installed in the Church of Nossa Senhora da Conceição, the current Cathedral of Mariana. In addition, this article will try to highlight the importance of the contract of the action of the carving work regarding the fulfillment of their contractual terms. This study is possible due to the existence of some primary documentation that shows the composition and organization of a carving atelier around the year 1749, which suffers criminal penalties for noncompliance with the terms and conditions of the contract of the auction of the carving work.

Keywords arts, work, gilt statue

\section{O retábulo de São Miguel e Almas da Sé de Mariana}

Dos diversos eventos desencadeados pelo processo de crescimento na Capitania de Minas, durante o século XVIII, destaca-se a construção arquitetônica religiosa, destinada a abrigar a fé de uma população onde as incertezas relativas à vida e à morte eram constantes, diante de um mundo onde tudo estava por fazer: a lei por instalar e a ordem por se estabelecer. ${ }^{1}$ Assim, o cenário coevo vigente trouxe grandes oportunidades para os artífices que por hora se encontravam na região de Minas, quando, no interior dos templos religiosos em elevação, a produção artística se fez plenamente presente por meio, principalmente, da pintura e da talha dourada. $^{2}$

Em Minas Gerais, o desenvolvimento da talha dourada foi possível devido à instalação de grandes oficinas no interior das igrejas, constituídas em prol de se cumprir os contratos de trabalho celebrados entre os oficiais e os encomendadores das obras. Tais ateliês ${ }^{3}$ constituíam-se em complexas estruturas organizacionais de apoio ao fazer artístico, entretanto, há muito para se conhecer a respeito dos modos pelos quais se organizavam.

1 Toda esta gênese, conforme Silveira, "contribuiu para a vivência de um ritmo de prosperidade, identificado com a criação de uma estrutura social inédita"; SILVEIRA, Marco Antônio. O universo do indistinto: estado e sociedade nas Minas setecentista (1735-1808). São Paulo: Hucitec, 1997, p.109.

2 Conforme Borges, a talha conferia ao interior das igrejas o movimento, contraste e riqueza que nem sempre a arquitetura era capaz de provocar. Sua aplicação ocorria em retábulos, púlpitos, paredes constituindo-se em elementos indispensáveis à arquitetura religiosa setecentista. BORGES, Nelson Correia. Do barroco ao rococó. In: $\quad$ História da Arte em Portugal. v.8. Lisboa: Publicações Alfa, 1986, p.47.

3 A pesquisadora Jeaneth Xavier de Araújo, em sua dissertação de mestrado, aprofunda as pesquisas a esse respeito. Ver: ARAÚJO, Jeaneth Xavier de. Para a decência do culto de Deus: artes e ofícios na Vila Rica Setecentista. Belo Horizonte: Universidade Federal de Minas Gerais, 2003 (História, Dissertação de mestrado). 
Nesse sentido, o presente texto traz ao debate relevante documentação, ainda pouco conhecida, ${ }^{4}$ que relata uma ação cível impetrada pela Irmandade de São Miguel e Almas, da Sé de Mariana, contra o arrematante da fatura do retábulo da referida irmandade, Félix Ferreira Jardim. Tal documento, além de ponderar a importância do contrato de trabalho com cláusulas bem definidas, elucida a composição básica de uma oficina de talha, coloca em discussão a importância do risco como ponto de partida para o trabalho artístico e demonstra o quão pontual era a atuação da justiça da Capitania, no tocante à solução de pendências judiciais. Por outro lado, não se pode deixar de mencionar a importância do documento ao relatar nomes de alguns artífices atuantes nas igrejas de Minas Gerais, contribuindo para que se possa conhecer a autoria de obras de talha das quais não se sabia quem foram os artistas responsáveis pela execução.

\section{A ação cível}

Em síntese, tem início o processo judicial no dia cinco de outubro do ano de 1749, quando a Irmandade de São Miguel e Almas, da Sé de Mariana, impetra ação cível contra Félix Ferreira Jardim, arrematante da obra de talha do retábulo da dita irmandade. Tal ação foi movida pelo descumprimento, por parte do réu, dos prazos contratuais que estabeleciam 385 dias para que a obra fosse finalizada. Assim, passados trinta e cinco dias após ter expirado o tempo pré-estabelecido para conclusão dos trabalhos, a Irmandade de São Miguel partiu em busca das sanções penais cabíveis, previamente estabelecidas no contrato de arrematação, que implicaram ao réu, Félix Ferreira Jardim, multa pecuniária de quatrocentas oitavas de ouro; além da expressa obrigação de finalizar a referida obra, no decorrer de quinze dias depois de proferido o despacho judicial.

Entretanto, na tentativa de se esquivar da decisão judicial, Ferreira Jardim diverge do veredicto, alega ser ilegal a ação e recorre à justiça solicitando sua anulação. Argumentou o réu não ter sido comunicado pessoalmente dos fatos, pois não estava presente no momento em que fora procurado pelo oficial de justiça, e apenas teve conhecimento de que estava sendo processado, por intermédio de seu vizinho: o renomado entalhador José Coelho de Noronha, quem assinou a intimação. Negado o pedido, lhe é ordenado cumprir os deferimentos judiciais.

Ainda em desacordo com as instruções expedidas pela justiça, Félix Ferreira Jardim argui que o atraso na entrega da obra fora motivado por

4 Arquivo da Casa Setecentista de Mariana - IPHAN (doravante, ACSM). Ações Cíveis, $2^{\circ}$ Ofício de Mariana Cód.251, Auto 6217. As informações arroladas no referido códice contribuem para que se possa compreender o funcionamento, a composição e outras questões que alicerçavam uma oficina de talha nas Minas Gerais do século XVIII. Esta importante fonte, levantada por Ivo Porto de Menezes, ainda não teve na historiografia da arte mineira o devido estudo a qual faz jus. 
inovações realizadas nas molduras do retábulo, promovidas a fim se modernizar a estética da talha e deixá-la atualizada com o gosto da época. Mesmo diante deste álibi, Ferreira Jardim tem novamente negado seu pedido para não sofrer as penas legais, visto que tais inovações foram frutos de sua iniciativa e não arranjos previstos no risco inicial da obra. Assim, não coube a Ferreira Jardim o direito de se refutar das cominações legais, sendo obrigado a ressarcir o contratante, conforme cláusulas contratuais, além de ter que finalizar a obra por suas próprias expensas.

\section{O contrato de arrematação}

O contrato de trabalho, elemento imprescindível para a execução de quaisquer serviços empreendidos no mundo luso-brasileiro no que se refere à produção artística e arquitetônica religiosa, constituía-se em primordial ponto de partida para a formação das oficinas de talha. Na ação cível em análise, exemplificam-se algumas questões que envolviam esses contratos, onde eram firmadas as condições e riscos da obra que se pretendia empreender. Estes documentos, imbuídos de valor legal, atuavam como base de suporte à fábrica dos retábulos, bem como à gestão da obra e das oficinas.

Assinado depois de arrematada a obra, comumente, um contrato de serviços de talha continha a data, o local e as testemunhas presentes no momento da arrematação; as especificações dos materiais a serem utilizados, os detalhes construtivos, o tipo de obra a ser feita, o local a ser realizada, valores do trabalho e formas de pagamento. Os direitos e deveres dos arrematantes e dos contratantes também eram listados, assegurando, a ambas as partes, acionar a justiça em caso de falha no cumprimento contratual para requerer multas e penas. Finalizava-se o documento com assinaturas dos contratantes e dos responsáveis pelos trabalhos. Em muitos casos, como no contrato do retábulo-mor da Matriz de Caeté, ${ }^{5}$ foi comum a presença de um fiador que arcaria com prejuízos advindos em situações de não efetivação dos serviços. Os fiadores eram a garantia do contratante de que, em caso de prejuízo, ele seria ressarcido. No tocante a essas questões, Félix Ferreira Jardim, ao firmar o contrato de trabalho ${ }^{6} \mathrm{com}$ a Irmandade de São Miguel e Almas, assume o papel de fiador da obra. Apesar de corriqueira a figura dos fiadores, tal informação vem a demonstrar ser ele um homem de posses, por possuir reservas financeiras capazes de suster possíveis prejuízos frutos de descumprimentos contratuais. Mesmo não se conhecendo a verdadeira faceta de Ferreira Jardim, possivelmente, pelos poucos relatos que se encontra a seu respeito, parece ter sido ele importante nome no contexto artístico nas Minas dos setecentos.

5 Arquivo Público Mineiro. Seção Colonial, Delegacia Fiscal, códice 1075, fl.104.

6 ACSM. Ações Cíveis, $2^{\circ}$ Ofício de Mariana, Cód.251, Auto 6217, fl.3. 
Dentre inúmeras outras informações que podem ser extraídas do referido contrato, destaca-se a importância do risco como elemento primordial para formatação das cláusulas que regiam tal documento. Assunto esse já trabalhado por estudiosos do assunto e constante em documentação coeva, mas que permite considerar, mais uma vez, que o encomendador, ao facultar a um entalhador a realização de uma obra, já havia definido qual seria a configuração estética e formal do trabalho que almejava que fosse realizado, com seus detalhes e riscos fixados previamente, ficando o entalhador contratado obrigado a seguir tais determinações.

No contrato em debate, constata-se que a obra deveria "ser posta na sua ultima perfeisão tudo na forma dos riscos e condisoins com que a justo a dita obra" ${ }^{7}$ Estes riscos e apontamentos eram, primordialmente, materiais de referência para o trabalho do entalhador. Além de funcionarem como paramento para que as pessoas interessadas em arrematar os trabalhos de talha calculassem prazos e custos relativos às obras e, desse modo, pudessem definir o valor pelo qual seria de seu interesse realizar o serviço. Eram delimitados, no projeto, a configuração da estrutura do retábulo, seus modelos arquitetônicos e elementos decorativos. Poderiam ainda ser apontados nestes riscos, características e especificidades referentes à pintura e escultura que os retábulos comportariam. Conforme Ferreira:

O risco, como peça fundamental na concretização da obra de talha e como
cláusula determinante de qualquer contrato de execução desta arte, detinha
pela sua natureza funções muito específicas no cômputo geral do processo
que culminava na obra acabada e "assentada em seu lugar". Em primeiro lugar,
permitia desde logo, que o encomendador ou encomendadores escolhessem o
modelo de retábulo que desejavam ver feito; em segundo lugar seria um precioso
auxiliar do mestre em todo o processo de trabalho, não só pela planta que apre-
sentava, mas também pelos apontamentos que geralmente a acompanhavam e
que o guiariam pela obra, referindo medidas, formas e ornamentos; em terceiro
lugar serviria de guia aos avaliadores que no final da obra confrontavam os
elementos do risco com o trabalho que efectivamente tinha sido executado pelo
artista, aferindo da conformidade do mesmo com a planta original, e julgando
se aquele tinha elementos em falta ou elementos em demasia relativamente ao
projecto inicial. ${ }^{8}$

Outra importante cláusula contratual, mencionada no documento em estudo, é o prazo de 385 dias no qual deveria ser finalizada a obra, o que contribui para que se possa estimar o tempo que tais empreendimentos levavam para ser finalizados. Dado este ainda pouco conhecido em relação à fábrica de obras de talha. Certamente não se devem considerar, para

7 ACSM. Ações Cíveis, $2^{\circ}$ Ofício de Mariana, Cód.251, Auto 6217,, fl.3.

8 FERREIRA, Sílvia Maria Cabrita Nogueira Amaral da. A talha barroca de Lisboa (1670-1720): os artistas e as obras. v.3. Lisboa: Universidade de Lisboa, 2009, p.154 (História, Tese de doutorado). 
trabalhos do mesmo gênero, prazos similares, pois fatores como complexidade do risco e dos objetos a serem confeccionados, dentre tantos outros, poderiam acarretar tempos diversos.

Apesar da exigência contratual de se seguirem os riscos e apontamentos, eram comuns obras de talha em cuja execução modificações estruturais fossem realizadas. Sobre esta discussão, torna-se significativo o conteúdo da ação cível, impetrada pela Irmandade de São Miguel e Almas contra o arrematante da obra do retábulo de sua devoção. A referida ação foi interposta por ter o réu descumprido os prazos e acordos contratuais e, em consequência, pela própria natureza das cláusulas contratuais, multas deveriam ser-lhe aplicadas. Diante das acusações, o réu se defendeu alegando que o atraso na entrega da obra foi devido às modificações nos riscos do retábulo que foram necessárias para promover melhorias e inovações. ${ }^{9}$ Tais melhorias teriam sido propostas por novo risco feito pelo entalhador José Coelho de Noronha. ${ }^{10}$ Neste caso, o embargante se julgava não obrigado a cumprir os prazos determinados pelo contrato, pois os acréscimos e inovações causaram prejuízos de tempo e dinheiro'11 e não foram frutos de novo contrato, nem contemplados no ato de arrematação. Modificações no projeto inicial de talha retabular eram comuns e muitos projetos finais se afastavam das configurações delimitadas no projeto inicial. Estas transformações ou acréscimos, como cita Bazin, ${ }^{12}$ ocorriam pelo fato de raramente o autor do risco ser o arrematante da obra, o que implicava intervenções do mestre, líder da oficina, nas plantas e riscos objetivando promover aperfeiçoamentos para adequar a obra a sua execução e também aos gostos estilísticos e artísticos em voga.

A ação cível demonstra também a importância das cláusulas contratuais que, uma vez não cumpridas, eram levadas à Justiça da Capitania para se proferir o veredicto sobre as reivindicações, demonstrando a força legal dos contratos e suas cláusulas bem definidas que visavam resguardar, tanto o contratante quanto o contratado.

Ainda no que concerne à arrematação de trabalhos de talha, deve-se destacar, novamente, que nem sempre a pessoa que recebia concessão para realizar os serviços era quem de fato os executava. No caso do retábulo de São Miguel e Almas, Félix Ferreira Jardim arremata a obra e não atua em sua fatura, ficando José Coelho de Noronha incumbindo de tal tarefa. Pela análise do códice se pode constatar tal assertiva, o que leva a crer ter atuado Ferreira Jardim como uma espécie de empresário, pois, simultaneamente, diversas obras dispersas pelo interior de igrejas existen-

9 ACSM. Ações Cíveis, $2^{\circ}$ Ofício de Mariana, Cód.251, Auto 6217, fl.18v.

10 ACSM. Ações Cíveis, $2^{\circ}$ Ofício de Mariana, Cód.251, Auto 6217,, fl.18v.

11 ACSM. Ações Cíveis, $2^{\circ}$ Ofício de Mariana, Cód.251, Auto 6217, fl.21v.

12 BAZIN, Germain. A arquitetura religiosa barroca no Brasil. v.2. Rio de Janeiro: Record, 1983, p.46. 
tes nas vilas de Minas Gerais, estavam sob sua responsabilidade, apesar de terem sido executadas por terceiros. Alguns desses serviços, inclusive, ocorriam simultaneamente como, por exemplo, a talha do retábulo de Santo Antônio da Sé de Mariana que, conforme o registro, ${ }^{13}$ fora arrematado por Ferreira Jardim e erigido em concomitância à obra do retábulo das Almas junto a alguns outros trabalhos realizados na Sé de Mariana para a posse do bispo Dom Frei Manuel da Cruz. O fato descrito elucida a arrematação e gerenciamento de três distintas obras por um mesmo responsável, Félix Ferreira Jardim.

Sobre a identidade pouco conhecida de Ferreira Jardim, pode-se inferir que fora peculiar seu envolvimento em ações judiciais por descumprimentos contratuais dos serviços por ele arrematados. Assim, ele aparece com diversas identidades e sempre se esquivando da polícia, como descrito no documento transcrito. ${ }^{14}$ Essas informações são merecedoras de estudos futuros, em busca de se conhecer quem fora, de fato, Félix Ferreira Jardim no contexto das artes e ofícios das Minas do século XVIII.

\section{A composição da oficina}

Um contingente de profissionais, de variados setores das artes e dos ofícios, constituiu a sociedade que se formou em Minas no século XVIII. Muitos desses homens, como pedreiros, carpinteiros, pintores e entalhadores, dentre outros, de distintas outras ocupações, se dedicavam a guarnecer, principalmente de talha dourada e pintura, os inúmeros templos religiosos que se erguiam.

Na Capitania de Minas, especificamente, peculiaridades diversas marcavam a organização dessa categoria de trabalhadores em relação a outras regiões do Brasil, bem como da Metrópole portuguesa. Entre muitos aspectos que contribuíam para acentuar tais diferenças, tem-se a grande mobilidade espacial de que desfrutavam, pois a vasta geografia de atuação era condicionada às oportunidades que surgiam, sendo esse um dos traços mais marcantes do labor dos profissionais que se dedicavam à arte da taIha. ${ }^{15}$ Concorriam assim, tais particularidades, para que as oficinas de talha não se condensassem em um pequeno núcleo urbano, pois as distâncias nas Minas eram muitas e as oportunidades de trabalho também o eram, fazendo com que os entalhadores fossem ao encontro das obras de talha que ocorriam, simultaneamente, em diversas partes do território. Logo, além do caráter de ambulante, eram marcadas pela efemeridade. Configuração essa um pouco diversa do que ocorreu em Lisboa no século XVIII, quando

13 ACSM. Ações Cíveis, $2^{\circ}$ Ofício de Mariana, Cód.251, Auto 6217, fl.32.

14 ACSM. Ações Cíveis, $2^{\circ}$ Ofício de Mariana, Cód.251, Auto 6217, fl.30v.

15 BOSCHI, Caio César. O barroco mineiro: artes e trabalho. São Paulo: Brasiliense, 1988, p.40-60. 
as principais oficinas, conforme Ferreira ${ }^{16}$ localizavam-se em arruamentos, próximas umas das outras, onde era realizada a talha e somente depois de concluída, levada à igreja onde seria instalada.

Nestas oficinas, simultaneamente, trabalhavam profissionais de variados ofícios. Além do mestre responsável, geralmente pela gestão dos serviços, carpinteiros, carapinas, ensambladores, entalhadores e tantos outros profissionais davam suporte aos serviços que se realizava. Este modo de produção da obra de arte e de organização do trabalho nas oficinas de talha retabular, no século XVIII, pode ser verificado por meio da ação cível em debate.

Conforme o documento supracitado, sete testemunhas arroladas no processo judicial estavam envolvidas na confecção do retábulo de São Miguel e Almas: Amaro dos Santos, mestre entalhador; José Coelho de Noronha, mestre entalhador; Manoel Gomes, mestre pedreiro; Manoel João, entalhador; Simão Franco Monteiro, carapina; Luiz Mendez carpinteiro e Antônio Pereira, de quem não fica explicita a ocupação. Das observações que se pode fazer diante dessas informações, a mais importante é a de que em um mesmo retábulo, simultaneamente, atuavam vários profissionais de distintas funções: três entalhadores, um pedreiro, um carapina e um carpinteiro, não se considerando os pintores que fariam acabamentos e o douramento da talha. Neste caso, os entalhadores eram os responsáveis pelo trabalho de escultura do retábulo, o carapina, pelo trabalho mais grosseiro de tratamento da madeira, como desbaste, corte e plaina, ${ }^{17} \mathrm{O}$ carpinteiro, por estruturar a madeira e o pedreiro que, segundo o documento, recebeu a "a diressão e risco para faser o arco". ${ }^{18}$

As informações referentes aos profissionais que atuaram na fatura do mencionado retábulo, contidas no códice em análise, exemplificam a organização de uma oficina de talha com relação à distribuição do trabalho, embora não houvesse mão-de-obra especializada para efetuar cada etapa existente na produção da talha retabular. As diversas áreas de atuação dos profissionais que compuseram esta oficina e o fato de todos estarem envolvidos, simultaneamente, na execução de uma única peça, permitem considerar que as partes estruturais constituintes de um retábulo e seus respectivos processos de produção eram realizados concomitantemente e não em separado. Essa constatação demonstra como ocorria a organização do trabalho em equipe com o objetivo de se alcançarem as metas engendradas por este tipo de fazer artístico.

16 FERREIRA, Sílvia Maria Cabrita Nogueira Amaral da. A talha barroca de Lisboa (1670-1720), p. 100.

17 MENESES, José Newton Coelho. Artes fabris e serviços banais: ofícios mecânicos e as Câmaras no final do Antigo Regime, Minas Gerais e Lisboa, 1750/1808. Niterói: Universidade Federal Fluminense, 2003, p.343 (História, Tese de doutorado)

18 ACSM. Ações Cíveis, $2^{\circ}$ Ofício de Mariana, Cód.251, Auto 6217, fl.29v. 
O arranjo do labor em um ateliê de talha pode ser considerado como resultado da orientação de um líder que, por ser detentor de vasto conhecimento do trabalho em execução, se encarregava de conduzir a obra e os profissionais nela envolvidos da melhor forma na busca de se alcançar as especificações e demandas explícitas pelo contratante. Nesse sentido, considerem-se duas citações do documento em estudo: a primeira, ocasião em que José Coelho de Noronha é rotulado "perito no ofício de entalhador"19 e a segunda, quando este mesmo entalhador - conforme relata o entalhador e testemunha no processo cível, Amaro dos Santos - recebe o aval do arrematante da obra do retábulo de São Miguel e Almas da Sé de Mariana, Félix Ferreira Jardim, para fazer o que entendesse na dita obra de modo que ela ficasse na melhor forma, o que de fato ocorre quando José Coelho de Noronha propõe soluções para o retábulo ficar com "mais galantaria e perfeição" ${ }^{20}$

$\mathrm{O}$ aval de Ferreira Jardim para que Noronha fizesse o que bem entendesse e as soluções que, de acordo com o documento, foram efetuadas e em consequência provocaram alterações no risco do retábulo, ratificam o destaque deste artífice na oficina em questão, fornecendo suporte para cogitar hipóteses de ser ele o entalhador mais experiente no referido ateliê, portanto, o líder para a coordenação dos trabalhos e nas tomadas de decisão em relação às direções que a obra deveria seguir.

A possível posição de Coelho de Noronha como líder pode ser um dos indícios de que os ateliês de talha dispunham de um "guia", responsável pela gestão técnica da obra empreendida. Esta condição de liderança ${ }^{21}$ poderia estar vinculada ao largo conhecimento sobre talha, ornamentação e arquitetura, pré-requisitos imprescindíveis àquele que estaria à frente dos respectivos trabalhos. São ainda essas as bases de formação para garantir perícia, técnica e diferenciar os oficiais do mesmo ramo de atuação, o que Ihes certificava fama, prestígio e posição de destaque em meio a seus pares.

Analisar essas oficinas, por meio da presença de um guia, permite avançar os conhecimentos referentes sobre o modo pelo qual se organizava e era gerido um ateliê de talha em Minas no século XVIII, visto serem perceptíveis, em uma peça retabular, configurações estéticas diversas, que,

19 ACSM. Ações Cíveis, $2^{\circ}$ Ofício de Mariana, Cód.251, Auto 6217, fl.33v.

20 ACSM. Ações Cíveis, $2^{\circ}$ Ofício de Mariana, Cód.251, Auto 6217, fl.34.

21 A possibilidade de existir um supervisor dos trabalhos de escultura, foi tratada por Wittkower, ao citar o modo como era efetuado o planejamento para esculpir em Atenas, demonstrando, assim, o papel dominante de um líder nos trabalhos de escultura. Apesar das distâncias temporais e culturais existentes entre a escultura em Atenas e a obra de talha em Minas Gerais, em ambos os casos, deve ter sido fundamental, para o desenrolar dos trabalhos de um ateliê de escultura, a presença de uma "mente dominante", o que nos permite cogitar a hipótese de que, nas oficinas de talha das Minas Gerais dos setecentos, existiu um líder que comandava o ateliê. Ver: WITTKOWER, Rudolf. Escultura. 2 ed. São Paulo: Martins Fontes, 2001, p.301.

"temos que admitir a existência de um cuidadoso planejamento a cargo de uma mente dominante, cuja função seria de dirigir a execução coordenada, da qual se encarregava um grande número de trabalhadores. Podemos supor que grande parte tenha sido realizada através de instruções verbais e de uma supervisão direta e constante". WITTKOWER, Rudolf. Escultura, p.24. 
entre outros fatores, revelam habilidades e marcas escultóricas comprobatórias de terem sido fruto do labor de mais de um profissional. Apesar de não ser crível que apenas um entalhador fosse capaz de realizar a talha de um retábulo, sem lançar mão de uma equipe de auxiliares, raramente citações documentais são encontradas com listas dos nomes e ocupação profissional de todos os componentes de uma oficina. Costumeiramente, apenas a pessoa do arrematante dos serviços era citada e por isso ficava, a ele, atribuída a autoria da obra. Tudo isso demonstra a necessidade de se repensar tal conceito, visto nem sempre o arrematante de um serviço de talha ser atuante em sua fatura, como ocorreu em situação similar arrolada no documento que fundamenta a presente pesquisa.

Pôde-se, desse modo, aprofundar conhecimentos sobre o assunto e conhecer a composição básica de uma oficina dedicada à arte da talha dourada. Por outro lado, a existência de um líder contribui para que se possa compreender a permanência, nas obras de talha retabular, de caraterísticas escultóricas de um único artista. Tudo isso permite cogitar hipóteses de ser o mestre de uma oficina, o profissional que atuava de modo substancial na supervisão dos trabalhos e na escultura de detalhes e acabamentos finais de algumas peças, deixando impressas, assim, marcas de seu estilo pessoal.

\section{Considerações Finais}

Tiveram como finalidade, as discussões realizadas nesse estudo, trazer a conhecimento parte do conteúdo da ação cível interposta pela Irmandade de São Miguel e Almas, por se sentir lesada no não cumprimento das cláusulas contratuais que regiam a confecção do retábulo de sua devoção. Das diversas possibilidades de análise do documento, com abundantes direções referentes aos modos de atuação da justiça da Capitania, bem como sobre o fazer artístico no século XVIII, priorizou-se demonstrar algumas peculiaridades existentes durante a execução das obras de talha, a importância do contrato de trabalho como amparo legal ao contratante e ao contratado, a composição técnica de uma oficina de talha e os modos pelos quais era realizada a gestão dos serviços.

O considerável volume de informações presentes no referido códice possibilita reconstruir diversas páginas, ainda em branco, da história da arte mineira. Nomes, anônimos e conhecidos, de artistas atuantes no período são listados no decorrer da ação. Pormenores de suas vidas, identidades e curiosidades do contexto social coevo também são descritos. Como exemplo, o nome de Félix Ferreira Jardim aparece em destaque e pistas são fornecidas na busca de se conhecer quem foi e qual papel teve no contexto artístico setecentista mineiro, visto ser cercada de dúvidas sua figura e atuação. No entanto, o renomado entalhador José Coelho de Noronha, que a sua época alcançou fama e prestígio, é citado e importantes 
direções a respeito de sua vida e obra, como sua participação na fábrica de diversos retábulos da Sé de Mariana, cuja autoria era desconhecida, são mencionados.

Por fim, ainda que não tenha sido foco nas argumentações que encabeçam as discussões propostas, torna-se relevante citar a necessidade de, em estudos posteriores, aprofundar conhecimentos referentes aos modos pelos quais procedia a justiça da Capitania na busca de solucionar conflitos judiciais, dados esses presentes no documento que subsidiou a referente pesquisa e que ainda encontram-se por ser investigados em sua totalidade.

\section{Transcrição 22}

\section{Ação Cível impetrada contra Felix Ferreira Jardim pela Irmandade de São Miguel e Almas da Sé de Mariana, 5 de outubro de 1749. ${ }^{23}$}

(fl.1) Aos officiaes da Irmandade de São Miguel e Almas da Sé desta cidade Felix Ferreira Jardim

Acção de Criminação

Anno de nascimento de Nascimento de Nosso Senhor Jesus Cristo de mil setecentos e quarenta e nove aos vinte e sinco dias do mes de outubro do dito anno nesta Leal Cidade de Marianna em cazas da morada da minha escrivão aos nomeados com da digo nomeado me foi apresentado a petição a diante a esta por parte dos Irmãos da Irmandade de São Miguel e Almas da Ssé desta cidade dado com o despacho nella [ante] do Doutor Francisco Angello Leytão juis de fora da dita cidade e seu termo pedindo e requerendo me the a [testasão] a outro [oficial] e inteiro comprimento do [outro] com [qual] for mensionadas averão de ir [por rasão] da mesma acção sam obrigado Ihes a estes com [ilegíve/] [ilegíve/] comprimento do auto [ilegível]. (fl.1v) De que para constar fis este termo de autuação e por constação Manoel de Almeyda Coelho Sampayo escrivão.

(fl.2) À Irmandade em 25 de setembro de 1749

Disem os officiaes da Irmandade de São Miguel e Almas da Sé da dita Irmandade que seu papel e qualidade [entende] se [obrigou] Felix Ferreira Jardim a dar completa e acabada aos vinte dias do mês de setembro próximo [pretérito] do corrente anno a obra retablo de obra com condisão

22 O códice foi transcrito em sua totalidade, com exceção das folhas 12, 12v, 38, 38v, 39 e 39v. Porém o estado de conservação do documento impossibilitou a leitura e entendimento de diversas palavras, justificando assim, a grande quantidade de colchetes existentes ao longo do texto. Os documentos foram transcritos de acordo com as Normas Técnicas para Transcrição e Edição de Documentos Manuscritos. Ver: BERWANGER, Ana Regina; LEAL, João Eurípedes Franklin. Noções de paleografia e de diplomática. Santa Maria: Editora UFSM, 2008. Manteve-se o uso de maiúsculas. A pontuação e acentuação foram transcritas conforme os originais.

23 ACSM. Ações Cíveis, $2^{\circ}$ Ofício de Mariana, Cód.251, Auto 6217. 
de que não satisfasendo ao referido perder quatro centas oitavas de pena condisional e poderão os suplicantes passado o dado tempo, mandallo [concluir] à vista do suplicado e por [qual] se finda o dado tempo e não satisfes o suplicado a sua condição podendo ainda por saber ou não para dar esta dita obra, que sem os suplicantes fisello nothificam para que no tempo de quinse dias a dá [concluído] na forma das condisões della com a [combinasão] de que não fasendo no referido tempo dado ella a mandarem os suplicantes com esta ir acento do suplicado, expulsão [dada que] para livres poderem nella trabalhar os officiaes a quem dita dar para dado official; [sem] o suplicado está usando das madeiras para dito [retablo] ou para estas portas aplicandoas para as mesmas, a que haver primeiro da dita entrada porque não tem como resarcir a falta das mesmas, [queira] ação de nothificar para que com pena de prisão ou não dar vista para outras obras, para que poça ser [feito].

Pede lhes a vossa mercê [ilegíve/] mandar que se nothifique o suplicado caso o referido com as [condisoens] expostas como hora certa que se esconda e proteja aos [?] suplicantes não renunciar pela proRogassão dos referidos que insidi as ditas que resta adquirido a dada pena condisional a que os mesmos darão nas mãos do escrivam. (fl.2v) Francisco Manoel Antunes meirinho do campo nesta Leal Cidade de Marianna e seu termo certifico que em virtude da petiçam e despacho de que cabe que [vieram] todos suplicantes fui adonde se achava o suplicado nesta cidade e sendo ahi lhe asinei essa e por me não aparecer deve trasella e me constar se escultou [?] asinei de outro na dita hora não o traser ao seu vizinho por nome Joze Coelho de Noronha o qual sedi e esperei [tado] e prometeo dar lhe parte como constou por elle que [ilegíve/] pela dita por todo os [conhecidos] na petição que lhe fez em vez de por lei em prezente certidão a qual atendem a 25 de outubro de 1749 annos. Francisco Manoel Antunes

(fl.3) Digo eu Feliz Ferreira Jardim que eu tenho juízo e combinado com a meza da Irmandade de inficionado de São Miguel das Almas estabelecida neça dita cidade a fazer lhe a obra da talha capela do mesmo santo pelo preço e quantia de mil e cem oitavas de ouro com a declarasão de se me dar trezentas oitavas de ouro tenho que principiar ao sentar obra dando eu fiador a esta quantia a satisfação da mesma meza e o resto depois de finda e acabada e terminada e porta na sua hultima perfeisão tudo na forma dos riscos e [condisoins] com que a justo a dita obra as condisoins são [?] por mim asignados e da mesma forma [?] dos riscos, os coais são também asignados pelo juiz da irmandade e serei obrigado a seguir os [perceijos] dos ditos riscos sem me apartar deles e condisoins esta obra darei finda e acabada, ao dia vinte de setembro de mil setecentos e coarenta e nove com condisão porém que não a dando finda e acabada a tempo [?] do 
dito dia perderei quatrocentas oitavas de ouro e em [pena] de faltar ao dito o juízo e a Irmandade na forma das condisoins a poder mandar fazer pelo resto do ouro que me estiverem devendo contanto que fiquem [ressalvas] as quatrocentas oitavas de [perdimento] para a Irmandade e outro asim serei obrigado a conduzir a [tempo] a senam as ditas [talhas] porque obrigo minha [pessoa] e banir havido e por haver a lhe completar com a dita obrigação e por verdade pedi e [rogeis] [?] e termo [ilegível] que este por mim fizece como termose asignação e me asigno como meu signal que costumo. Cidade de Marianna primeiro de setembro de 1748. Como atesto que este fiz. Felix Ferreira Jardim

(fl.5) Aos vinte e nove dias do mês de outubro de mil e setecentos e quarenta e nove annos nesta Leal Cidade de Marianna em cazas de morada de minha posição abaixo nomeado me foi apresentada a petição ao diante santo por parte do réo, Felix Ferreira Jardim de que para constar fiz este Termo de apresentação, Manoel de Almeyda Coelho Sampayo escrivão que escreveis.

(fl.5v) Em 25 de outubro de 1749.

(fl.6) Diz Felix Ferreira Jardim, que elle tem nesta por parte da Irmandade, e mais Irmãos das Almas da Seé desta cidade se fisera huma petição contra o suplicante em que pedião se estasse [?] para dentro em 25 dias a acabar a obra do retabloo do altar das mesmas, com cominasão de perder quatrocentas oitavas, e ser prezo; de que se passara feé [?], sem nada o suplicante se citado na sua própria pessoas estando, como está atualmente assistindo nesta cidade, Ihe consta juízo procedendo a revelia; e porque tem que allegar; dita citação;

Pede-lhes a vossa mercê mandar se lhe continue vista para diser o que se oferecer de sua Irmandade.

(fl.6v) Procuração ao Doutor Maya Brandão Reys Mendonça

Aos vinte e nove dias do mês de outubro de mil e setecentos e quarenta e nove annos nesta Leal Cidade de Marianna em casas de morada de mim escrivão abaxo nomeado apareceu perante Felix Ferreira Jardim e para que me foi dito que para aparente causa e suas dependências [possão] [?] os procuradores aos doutores João da Costa Braga e foi aotuado [ilegíve/] fes Jacinto Furtado de Mendonça ao paso que cada huma do pressinto [?] [ilegíve/] hum possão requerer todo o seu direyto e restrição pellas aprovações e embargos juros em sua alma todos o dito [?] juramento de collumnia passados para que [?] conceda todos os poderes em direitos necessários e o dis por Manoel de Almeyda Coelho Sampayo escrivão. Fellix Ferreira Jardim 


\section{(fl.7) Termo de Visto}

Aos vinte e nove dias do mês de outubro de mil setecentos e quarenta e nove annos nesta Leal cidade de Marianna em cazas de morada de minha escrição abaixo nomeado [assinou] visto destes autos o doutor João da Costa Braga a procuradoria Felix Ferreira Jardim de que para constar fis este Termo de Visto Manoel de Almeyda Coelho Sampayo escrivão.

Pede a vossa mercê afim de julgar nulla a citação que se fez a folha 2, e certidão da mesma dita folha 2, dis o embargante na melhor forma de direito. Por que as sitaçoens devem ser feitas (fl.7v) nas próprias pessoas, que se demandão para qualquer acção, o que he expresssa determinação da ordem do [tribunal], e fasendose dentro insiste, fica tudo quanto possa mesma se abra nulla, por ser a dita citação o princípio, e fundamento do juizo [contencioso].

Porque só nos casos expressados na referida ordem, he que se poderia aquela citação ser feita por ditos, não se sabendo do lugar certo, ou na pessoa de hum familiar da casa, e ainda visinho, quando constasse, que havia de ser citado se [ilegíve/] e para isto o devia procurar o quão veres, para asim Ihe constar, o fasia.

Porque logo sem mais diligências, hindo o official (fl.8) a caza do embargado [para] a citar, Ihe asignou hora, sem anotar na pessoa de quem; pois o não declaro a certidão; e passada ella, dis que o estará na pessoa de Jozé Coelho de Noronha, por ser vizinho do supplicante embargante.

Porque cazo negado, ainda assim a dita citação poderá permitir [?], nunca se achava na forma da ley, assim por não fazer diligência pessa embargante, que no cazo de não se achar, Ihe constar verdadeiramente, ser [culpado], hé que poderia citalo pelo modo que se acha; mas também porque para haver de citar ao mesmo embargante na pessoa de Jozé Coelho de Noronha, a elle hé que poderia assignar the as duas horas para the dar parte, e o fazer certo da referida citasão o que não o fes.

(fl.8v) Porque embargante assiste nesta cidade, e tem caza certa onde asiste, e mora, e nunca se ocultou, antes naquele mesmo dia andou perante a cidade a vista de todos, e falou com algumas pessoas, e nunca teve nesta dita sem a citação, e semelhante [?] pedio o dito Jozé Coelho de Noronha que hum official de justiça Ihe lera uma petiçam sem Ihe dizer mais circunstância alguma, nem que lhe tinha asignado as duas horas [?]; para que assim der, o havia logo de procurar, assim como se fez, tanto, que o avisarão, de que a dita citação se tinha acuzado.

Porque nos referidos termos e confirmasoens de direito a prezente citasão se deve julgar nulla, por ser feita contra a formada ley, e consequentemente, tudo o que em (fl.9) virtude da mesma se fizer, e obrar, e que quererem neste termo continuar na citasão para diante se torna o embargante novamente a [citasão] [?] do official, que fes a nulla citação; o que asim se espera, recebendo-se para esse fim os prezentes embargantes. F.J. 
Data Aos vinte e hum dias do mês de outubro de mil e setecentos e quarenta e nove annos nesta Leal Cidade de Marianna em cazas de morada de mim escrivão abaixo nomeado me forão autos por parte do Doutor João da Costa Braga procurador do Reo (fl.9v) com os seus embargos tenho de que para constar fis este term de data Manoel de Almeyda Sampayo escrivão que o escreveis.

Termo de Conclusam [?]

Aos vinte e hum dias do mês de outubro de mil e setecentos e quarenta e nove annos nesta Leal Cidade de Marianna em cazas de morada de mim escrivão abaixo nomeado dito estes autos com o caso ao Doutor Francisco Angello Leytão juis de fora nesta cidade e seu termo de que para constar fis esta de conclusão Manoel de Almeyda Coelho Sampayo escrivão que o escreveis.

Sem embargo aos embargados que não recebo responda o processo diretamente no termo [?] de [autores] [?] à notificação, visto estar siente della; e pagar os custos dos embargos.

\section{Publicação}

Aos seys dias do mês de novembro de mil e setecentos e quarenta e nove annos nesta Leal Cidade de (fl.10) Marianna nos passo do conçelho devo em publicou de inissio as ditas partes e seus procuradores e estava fasendo o Doutor Manoel Ferreira por comissão do Doutor Francisco Angello Leytão juis de fora nesta cidade e seu termo de que para constar fis esta declarasão, Manoel Almeyda Coelho Sampayo escrivão que escreveis.

Termo de Visto

Aos seis dias do mês de novembro de mil e setecentos e quarenta e nove annos nesta Leal Cidade de Marianna em cazas de morada de mim escrivão abaixo nomeado continuo lista e ditos autos ao Doutor João da Costa Braga procurador do reo de que para constar fis este termo de vista, Manoel de Almeyda Coelho Sampayo escrivão que escreveis.

Visto do Doutor Maya

Por embargar a notificação folha 2 afim de que por ella senão proceda, e nem obre como alguma, dis o embargante na melhor forma e via de dito. (fl.10v) Porque ajuntando os officiaes das almas da Seé desta cidade com o embargante a feitura do retablo do altar das mesmas, Ihe darão as condisoens do papel a folha 2, e se asignou a fazelo na mesma forma que se achão expressadas.

Porque nesta confirmidade continuou o dito embargante a fazer a referida obra, para o qual já tinha lavrado muitas peças de molduras de volta, contras talhadas, as quaes expressarão a seu tempo, por rol [?] que delas há de fazer. 
Porque estando assim continuando o embargante com as molduras, e sendo feitas iam muitas na forma das condisoens do dito papel, inovarão os embargados à obra em que se achão de (fl.11) assentar as molduras, e retablo, fazendo na parede do altar das mesmas almas retiro para tras, devendo les divista, na forma das condisoens do papel; por cuja cauza ia o mesmo embargante onde está abrigado a cominassão, ou condissão que lhe puserão de perder quatrocentas oitavas, senão findasse obra no tempo convencionado.

Para que possa referida inovassão que os embargados fizerão na parede do altar das dias almas, foi o embargante perdendo as molduras que já havia feito, sendo, na forma que ajustarão, o dito retablo direto, e não com retiro, e plantas novas que novamente fizerão, as quais Ihe devem pagar os embargados por não ser elle o que deo cauza a dita inovassão.

Porque para a referida planta e retiro (fl.11v), hé melhor [?] lavrar o embargante outras molduras, por não poderem servir as que se achão feitas, lavradas, e nesta forma, não esiste da parte do embargante a não se acabar a obrar, pois senão fora a sobredita inovassão estaria já de todo acabada, ou a menor preço Ihe faltaria.

Porque disso the não deram clareza, e menos fizerão obrigassão de quem havia de pagar a dita obra, e somente devia [?] dito Coelho Pena, Ihe prometeo pagar tudo; e concorrer com vários e lhe findar a obra, o que não tem feito, e só a princípio hé que lhe derão algumas oitavas, de que passou recibos, delles constará o que hé.

Porque pedindo o embargante obrigassão ao dito [dever] parte, e andou este [peleando] alguns tempos, disendo Ihe não tinha dúvida, porém hé à prezente e não sem feito, e como para se esibirem pleitos para o futuro, necessito dela, sem que hajão de passar, não deve também ser obrigado a (fl.12) acabar a referida obra ${ }^{24}$.

(fl.12v) Particularmente [?] e como [?] de dita protestassão necessária E que se ajuntem as conddisõens para a vista della servir [?] melhor no conhecimento do expendido.

\section{(fl.13) Termo de Visto}

Os outo dias do mes de novembro de mil setecentos e quarenta e nove annos nessa Leal Cidade de Marianna em casas de morada de mim escrivão baixo nomeado me forão dados estes autos por parte do Doutor João da Costa Maya procurador do Reo com os seus embargos [retro] de que para constar fis este termo de vista, Manoel de Almeyda da Costa Sampayo escrivão [escreveis].

24 Suprimidas da transcrição folhas 12 e 12v. 
Termo de conclusão

Aos outo dias do mês de novembro de mil setecentos e quarenta e nove annos nesta Leal Cidade de Marianna em casas de morada de mim escrivão abaixo nomeado faço estes autos conclusos e o Doutor Francisco Angello Leytão juis de fora nesta cidade e seu termo de que para constar fis este de conclusão Manoel de Almeyda Coelho Sampayo escrivão o escreveis [?]. Leu aos embargos a parte ao contrário [?]

\section{(fl.13v) Publicação}

Aos des dias do mês de novembro de mil e setecentos e quarenta e nove annos nesta Leal Cidade de Marianna nas posses do concelho della em publica audienssia que as ditas partes e seus procuradores estava fasendo o Doutor João Dias Ladeira por comissão do Doutor Francisco Angello Leytão juis de fora nesta leal cidade de seu termo diz na dita audienssia por elle dito doutor juis comissário foi publicado o despacho retro que mandou se cumprisse como nella e costumes e declara de que para constar fis este termo de publicação Manoel de Almeyda Coeho Sampayo escrivão escreveis

Apresentaçam da petiçam do dito

Aos desoito dias do mes de novembro de mil setecentos e quarenta e nove annos nesta Leal Cidade de Marianna em casas de morada de mim escrivão abaixo nomeado me foi apresentado a procuração ao diante juntas por parte dos autores de que para constar fis este termo de apresentação Manoel de Almeyda Coelho Sampayo o escrivão que o escrevis.

(fl.14) O juis e mais os officiaes da Irmandade de São Miguel e Almas da matris desta cidade pello verem ao nosso alvará de procuraçam constituhimos e faremos nossos procuradores aos senhores doutores Manoel Bento [?] Maria, Jacinto [?] Ferreira dos Santos, João Dias Ladeira solicitadores Miguel Peixoto de Araujo e Jacinto Furtado de Mendonça para que todos juntos acordo [?] precisam [?] solicitam possam procurar requerer e alegar mostrar e defender o direito e sortirse na causa que a mesma irmandade fes com Felix Ferreira Jardim e de coalquer despachem sentença prevista a seu favor consentirão do correto e aposar agraciar embargar e jurar em suas almas coalquer [ilegíve/] juram o de calunia para que [ilegíve/] consedemos todos os poderes em direito necessários da dita e paçada e mesmo em mes de novembro de 1749 annos [?] Eu Gregorio Maria Neves que o escrevi que asignei. Gregorio Maria Neves, Domingos Pinto Coelho Penna,João Ferreira Farya

\section{(fl.14v) Termo de Visto}

Aos desesete dias do mes de novembro de mil e setecentos e quarenta e nove annos nesta Leal Cidade de Marianna em casas de morada de mim escrivão abaxo nomeado continuo vista destes autos ao Doutor Manoel 
Bras Ferreira procurador dos autores de que para cosntar fis este termo de visto, Manoel Almeyda Coelho Sampayo escrivão o escreveis.

Visto ao Doutor Ferreira

Contrariando [?] disem os embargados por esta, e [pelo] [?] vio mi[ilegíve/] de [ilegível] embargante.

E vindo nessa [?]

1 Porque he menos verdade dizendo [?] o embargante que os embargados inovarão a obra do retablo de que se trata porque o querião feita, e acabada na forma das condisoens expressadas no papel folha 3 e não de outra somente [?] e nem para deixar de cominar [ilegível] tendo taxado no seo papel teve o mesmo embargante $\mathrm{m}[?]$ via algun, porque

2 Porque inovarão a dita obra, e foi o mesmo embargante iam (fl.15) juntamente com os officiaes que trabalharão nella, porque asentarão [?] [ilegíve/] e chamado [?] retablo [?] [ilegíve/] a mesma comminassão [ilegível] e que [ilegível [ilegíve/] seguia ao embargante previsto [ilegíve/] [ilegíve/] ainda que em alguma parte do retablo, Ihe [ligava] mais algum palmo de moldura se fasia em menos tempo, e algum menos trabalho, porque não levava dois pillares, que havia de ter sendo feito na forma das condisoens, e que duas colunas, que levava [ilegíve/] mais pillares [?] nos quais [ilegíve/] pensa da [ilegível] [ilegíve/] [ilegíve/] [ilegíve/] nisto o embargante deves visto asignado. 3 Porque derão parte os embargados do referido por lhes [corroídas \pm 1 linha]

4 Porque o supposto referido nenhum prejuiso causarão os embargados ao embargante com verdade da dita obra nem ella recebeo instrumento [?] algun, porque a factura da mesma Ihe não havia [corroído] a da primeira na forma [corroído] madeira [?] para [linha corroído] embargados [linha corroída].

$5 \mathrm{E}$ para a obra do dito retiro ficar na forma, em que o embargante, (fl.15v) a ideia de como queria elle melhor [?] [ilegíve/] direção, e [ilegíve/] [corroído] se faser para, o direito [corroído] o tipo da parede da suas partes [?] [corroído] no retablo.

6 Porque he menos verdade diser o embargante [corroído] por [?] causa [forão] referidas [linha corroída] a obra do dito retablo, porque nenhum [compareseu] e mais do que the havia de suas para, e por asim ser.

7 Porque mesmo o embargante temia [?] por o não acabar dentro d[linha corroída] oitavas dep[trecho corroído] das madeiras do retablo, de que se trata [corroído] alegares [?] as mesmas para e das as ditas toras, e por este motivo não tenha [ilegível] saber despedio o embargante e outro [corroído] retirado [?].

[Integralmente corroído e ilegível] 
9 Porque tendo os embargados somente a obrigassão de darem (fl.16) ao embargante no principio da dita obra [?] tresentas oitavas de ouro e o resto, no fim [?] da mesma como se he [?] no papel do dito folha 3 estando a maior parte della por acabar, tendo [?] embargante recebido por conta da mesma duzentos [?] [outenta] e [?] pouco maiores partes, e [ilegíve/] de como [restante da linha ilegíve/] não acabou a dita obra no tempo admitido [?] no referido papel não só della não teve causa [?], mas [ilegíve/] ia he devedor o embargante a que supposto.

10 Porque nos termos referidos, e pela [?] forma de direitos embargos referidos do [ilegíve/] [corroído] [ilegível] [corroído] para os embargos delles [1 linha corroída e borrada].

Pelo visto [direito] com todos os protocolos numerados [?] de pedimento do embargante tem esta para fora dando mesmo melhor visto [?]. Ferreira Regimento de audienssia que foy recebida a contrariedade e justiça [?] hua audienssia a parte para replicar de forma os ditos [mag.es].

Aos vinte dias do mes de novembro de mil e setecentos e quarenta e nove anos (fl.16v) nesta Leal Cidade de Marianna nas posses do concelho della em publica audienssia que os autores e partes e seus procuradores estava fasendo o Doutor Manoel Bras Ferreira por comissão do Doutor Francisco Angello Leytão juis de fora desta cidade e seu Termo [corroído] dita audienssia pelo dito Doutor juis comissário e como procurador dos autores foi dito ao Doutor Paullo de Sousa Magalhães a deelegou para deferir o seu repe[?] mento, que [corroído] destes autos [corroído] a contrariedade requeria lhe ouvisse por oferessido e recebido lhe [?] inquantum tanto quoanto direito lesado receber segundo forma da ley, e asignasse hua audienssia a parte para replicar o que tudo visto e ouvido para o dito doutor juis comissário seu requerimento, (fl.17) informado dos termos dos mesmos autos que apresentou e ouvio a dita contrariedade pois [?] se fisesse da e recebida hua inquanto em tanto [?] quanto em direito hera direito de receber seguindo e tornado ley e asignou hua audienssia oposta para replicar de que para constar fis este termo tomado por contrariedade por [cota] reportado elle das audienssias donde a pessoa [?] o quis para constar do referido o que me reporto, Manoel de Ameyda Coelho Sampayo escrivão que o escreveis.

Termo de Visto

Aos vinte e hum dias do mes de novembro de mil e setecentos e quoarenta e nove annos nesta Leal Cidade de Marianna em cazas de morada de mim escrivão abaxo nomeado continuo visto destes autos ao Doutor João da Costa Maya procurador do reo de que para constar fis este termo de visto, Manoel de Almeyda Coelho Sampayo escrivão que o escreveis. Visto do Doutor Maya 
[Inreparando], que estive impedido por moléstia, e ocupações, e esta causa porque não despachei estes autos, sirvasse vossa mercê concederme tres dias, e por [im.to] [?].

Maya

\section{(fl.17v) Datta}

Aos vinte e cinco dias do mes de novembro de mil e setecentos e quoarenta e nove annos nesta Leal Cidade de Marianna em cazas de morada de mim escrivão abaxo nomeado me forão dados estes autos por parte do Doutor João da Costa Maya procurador do reo como se consta [?] lesado de que para constar fis este termo de data Manoel de Almeyda Coelho Sampayo escrivão que o escreveis.

\section{Termo de apresentacam}

Aos vinte e sinco dias do mes de novembro de mil e setecentos e quoarenta e nove annos nesta Leal Cidade de Marianna em cazas de morada de mim escrivão abaxo nomeado me foi apresentado a petição adianto auto por parte dos autores de que para consta fis este termo apresentação Manoel de Almeyda Coelho Sampayo escrivão que o escreveis.

(fl.18) Disem os officiaes da Irmandade de São Miguel das Almas da See desta cidade continuandosse com visto ao advogado de Felix Ferreira Jardim os auttos do embargo, com que o suplicado se oppos a nothificação que Ihe [fes] por parte dos supplicantes para replicar de seo o [?] meo passado o termo [?] legal da sua cota pedindo nella tres dias para depois delles, e porque por criar [?] [móras], não tem os suplicantes devida [?] importância [?] Ihe torna [?] para a dita obra, o que fassa a até a primeira com pena de infalível lansamento.

Como pedem para a vossa mercê lhe fassa mandar que Ihe continue novamente com vista e que replique até a primeira com a pena cominada, e que passado aquele tempo não fasendo, Ihes os [?] cobre logo os auttos como manda.

(fl.18v) Replicando, dis o embargante na forma mais [?] de disto [?] E sendo necessário

Porque achando se o embargante fora desta cidade em uma bossa acabando de fazer as madeiras, que lhe faltarão para a obra de que se trata, e neste tempo, com alsencia do dito embargante, fiserão os officiaes da Irmandade das Almas a innovasão da obra acrescentando-Ihe o retiro para trás contra a forma da primeira obrigaçam, que era de ser somente direito. Porque para esta inovassão, que os ditos officiaes o fiserão na obra de que se trata, chamarão a hum official que o embargante em caza por nome Jozé Coelho, que por the diser ficaria asim melhor, (fl.19) logo mandarão fazer o 
retiro para trás, sem darem parte ao embargante, a quem o deverão primeiro manifestar para ver se elle convinha, ou não [?] na dita innovassão, como parte prejudicada, erão ater justo daquela [forma].

Porque recolhendo-se o embargante das parage em que se achava para esta cidade, e sendo me [?] dita da referida innovassão; foy logo a caza de Domingos Pinto Coelho Penna, requerendo-lhe fiseram meza, para nova condisões; por Ihe não serviram as que tinhão asignado, innovandose a obra com o retiro, por lhe vir a causar prejuízo grave nas madeiras, que já tinha fabricado para a obra dita na forma que tinhão tratado.

Porque alem do embargante Ihis falar com (fl.19v) o dito Domingos Pinto sobre a innovassão que lhe tinhão feito na obra ter consentimento seu falou o mesmo embargante ou [?] outra pessoa que a seu tempo declarará, para [falar] aos ditos officiaes, em ordem a lhe evitarem o danno, que lhe causarão com o referido retiro a qual propôs ào juis da mesma irmandade a queixa do embargante, e lhes respondeo, que tal não havia de consentir, por estar a obra no primeiro risco à sua satisfação, e que asim se havia de faser.

Porque hé falso diserem aos embargados, que a obra de retiro para trás não prejudica ao embargante, e que leva as mesmas madeiras, que a que se tinha ajustado, a principio ainda por encarecimento, porque tanto conhecerão os mesmo embargados o contrário [?], que quando o embargante foy ter com o dito Domingos Pinto Ihe prometeo que Ihe havia de satisfaser todos os prejuízos, que a [?] dita innovassão lhe causassem, o que foy em presença dos officiaes, quando acção se achando na dita obra, que muito bem o perceberão, e estão promptos para depor a verdade.

(fl.20) Porque não obstante aquela promessa, que o dito presente fes ao embargante, sempre este reclamou, que os prejuízos eram grandes, e os acrescimos excessivos, tendo em sima de todas estas cousas varios dos atos com o dito Coelho, por se querer introduzir a [?] madeira, não sendo capas disso, e intrometerse com a obra, que ja ajustada pelo embargante, o que só fes por indicações dos mesmo officiaes.

Porque depois de varios debates, e andarem palsando os embargantes, para que fizesse (fl.20v) a obra pelo risco do retiro, o prometerem, que haviam de lhe pagar todos os prejuízos, e acrescimos, que houvessem, vindo os embargantes os [regir] importunos do erro [?] e mais officiaes concedendo com o seu visto [?], sem athender ao risco que o dito Coelho havia dado ou elleição lhe fes hum risco, que a ser feito, como elles querião, só aquele hé que poderia dar lugar e não ao outro.

Porque para isso era necessário preparar o dito embargante novas madeiras porque das que estavão lavradas presas sem risco [?], e nesta forma ia o embargante estava desonerado [?] de dar finda no tempo, que tinham pactuado nas primeiras condisoens; e em quererem o acordado [?], pelo requerimento que fiserão a abreviatura [?], não the obrarem com lisura e verdade, na forma do primeiro ajuste, mas sim com dolo grande, e quere- 
rem fraudar ao (fl.21) embargante e ao obrigado ao que ia não [está res] trito pela innovassão que fiserão, e talvés, que a diligência que fiserão em Ihe acolher o risco, seria para melhor conseguirem seu intento, o que the não pode ser [porficuo].

Porque como o thermo, Ihe prometeu resarcir todos os dannos, e acrescimos, que o embargante tivesse por causa da referida innovassão, e agora obra o contrário, não somente não deve ser compelido a trabalhar na dita obra com a innovassão, mas aliviado de dar finda no tempo cominado, por serem os embargantes o que derão causa a isso, pois só então seria admito o seu requerimento, se o embargante não dera acabada a obra no tempo cominado, sem elles faserem as innovassoens que fiserão.

(fl.21v) Porque nos referidos termos, conforme aos de visto, a cominação se deve julgar nulla, e o que o embargante não está obrigado a acabar a obra no tempo cominado, atentos as [rasões] ponderadas; e que o quererem obrigalo [assim] trabalhar, Ihe devem porque fazer bem, e seguro os proprios acrescimos que houver na dita obra, o que asim se deve mandar. Procedimento e cumprimento da dita protestasão vista.

\section{(fl.22) Datta}

Aos vinte e seis dias do mes de novembro de mil e setecentos e quarenta e nove annos nesta Leal Cidade de Marianna em cazas de morada de mim escrivão abaixo nomeado, petisão [dados] estes autos por parte do Doutor João da Costa Maya, procurador do reo com suas replicas retro [?], de que para constar fis este termo de data, Manoel de Almeyda Coelho Sampayo escrivão que o escreveis.

Referente de audiênssia em que fas a offerecida a replicar recebida [susing] [?] prova hua audienssia para treplicar

Ao primeiro dia do mes de desembro de mil e setecentos e quarenta e nove annos, nesta Leal Cidade de Marianna nas posses do concelho della em publicasãao audienssia que as vistas partes e seus procuradores estava fasendo o Doutor João Dias Ladeira por comissão do Doutor Francisco Angelo Leytão juis de fora nesta cidade e seu termo o fes [?] na dita aidienssia pello sollicitador de causas Jacinto Furtado de Mendonça procurador do reo foi dito que elle tinha dado este autos [?] com sua replica e requeria Ihe [?] audienssia publica ciente [?] quantum tanto que ante em direito hera sua replica quando a forma da ley, e asignasse hua audienssia a parte para replicar, o que tudo visto e ouvido, pello dito doutor juis comissario hum requerimento informado nos ditos modos isto por mim escrivão ouvio dita replica por oferecida e recebida hum quantum tanto que ante em direito hera de receber segundo os termos da ley, e asignou huma audienssia a parte para treplicar de que para constar fis este termo tomado por cota na parte como das audienssias onde as pessoas o [?] que para constando referido por me reporto Manoel de Almeyda Coelho Sampayo escrivão que o escreveis. 
Termo de visto

Aos dose dias do mes de desembro de mil e setecentos e quoarenta annos nesta Leal Cidade de Marianna em cazas de morada de mim escrivão abaxo nomeado conituo visto destes autos do Doutor Manoel Braz Ferreira procurador dos autores de que para constar fis este termo (fl.23) de visto Manoel de Almeyda Coelho Sampayo escrivão que o escreveis.

Visto do Doutor Ferreira

Treplicando disem os embargados por esta e pella via milhor dizendo [?] o seguinte.

E sendo nessa

1 Porque he falso e totalmente opposto a verdade diser o embargante que o dito estava em hua rossa fora desta cidade e que iniciou [?] a obra do retablo, de que se trata, porque o mesmo embargante antes de hir para a dita [rossa] [ilegíve/] os officiaes que [?] trabalhavão na obra donde chamado retiro [corroído] as madeiras mais [ilegíve/] quaes embargados the falarão, e insistirão nella foi para o dito embargante com os mesmo officiaes lhes dicerão em nada prejudicava a dita innovassão, por não haver acrescimo no presso da obra.

2 Porque o embargante [idou] o dito retiro porque sempre teve empenho com a obra do dito retablo fisesse para [ilegíve/] do altar da nossa Irmandade do Rosario, por isso, tambem pella mudansa della Ihe não causar prejuiso, contentou, pois não he dever, que se lhes fosse prejudicial e fisesse por devossão não lhe tendo falado nisso os embargados como hão de jurar os mesmo officiaes, que nella trabalharão.

(f.23v)

3 Porque por conhecer os embargados no embargante diser de que a obra do dito retablo excedesse a da dita mesma do Rosario, se moverão a darlhe no ajuste, que com elle fiserão, mais dusentas outavas de ouro, porque tendo quem Ihe fisesse por novecentas outavas como o embargante [ilegível] prometer ao mesmo [?] mantém como se mostra na obrigassão folha 3, e por este motivo, tãobem por diser que o embargante lhe dava cabal satisfassão por ignorar officio de entalhador, se quis esmerar no dito retablo variando direito, ainda com que os melhores materiais e trabalho. 4 Porque tanto he verdade o referido, que na septima arte de sua replica, contenssa o embargante fes dado o risco para o dito retiro, sendo que he falso diser o mesmo que os embargados [?] prometerão [ilegíve/] porque tal não [trecho ilegível] de mostrar, porque para o contrario hão os mesmos embargados de faser certo, por [corroído] ser [ilegível] do embargante [corroído] do dito motivo, milhor o mesmo mais a elle.

5 Porque depois que os embargados ajustaram com o embargante, a obra do dito retablo, vierão nesta, que o mesmo era acostumado a faltar aos ajustes, que tractava, e que nenhum das supposissão acabava, retirandosse 
fugitivamente, depois mudava o nome, porque chamandosse Felix Ferreira Jardim, e fugindo do Rio das Mortes por Sanches Bandeira, o mudara para Joseph da Silva Pinto, e que tem outros defeitos que por modestia se calão e omitem, e por isso, se lhe não pode estranhar, que recorra a defesa, que a se acha, pois agora se retirou tãobem fugitivamente desta cidade.

(fl.24)

6 Porque o embargante não deo concluida a obra do dito retablo no tempo estipulado na obrigassão dita folha 2 porque o empregou das outras obras, que tomou para os quaes aplicou tãobem as madeiras paitinadas para o dito retablo, e este foi o total motivo de não o concluir dentro do referido tempo. 7 Porque se o thesoureiro se tivera obrigado a pagar ao embargante pello dito retiro algua cousa mais de que aquillo, porque os embargados o ajustarão a obra do retablo, Ihe não queria de faltar a satisfaser Ihe, porque não querendo os officiaes continuar a trabalhar no mesmo por desconfiarem que o embargante não lhe satisfaria o seo trabalho, e querendo levantar mão da obra, para que o não fisessem se lhes obrigou de palavra o dito thesoureiro a satisfaserlhes, e deves [?] pagar promestamente, e da mesma sorte o havia praticar com o embargante, se lhe tiver prometido, porque não costuma faser o que promete, o que supposto.

8 Porque nos referidos ditos, e conforme os direitos, os embargos recebidos se devem julgar não provados, condenandosse o embargante a que no termo cominado na petiçam folha 2 concluia a obra do dito retablo com a pena declarada na dita petiçam, e asim se espera.

F.S.

Pelo visto ajuste com todos protestos nessas melhor [?] em [verdade] Ferreira

(fl.24v) Requerimento de audienssia em que foy offerecida treplica recebida [sussing] em prova de $\mathrm{x} x$ dos t e marca.

Aos quatro dias do mes de desembro de mil e setecentos e quoarenta annos nesta Leal Cidade de Marianna nas posses concelho della em publica audienssia que as testemunhas estas partes e seus procuradores estava fasendo o Doutor Francisco Angello Leytão juis de fora desta cidade e seu Termo o fes na dita audienssia pello Doutor Manoel Braz Ferreira procurador dos autores, foi dito a elle dito doutor juis de fora que elle deu a estes autos com a sua treplica requeria Ihe ouvisse por oferessida e recebida hua inquoantum tanto quanto em direito hum [?] de receber segundo forma e ley, e mandasse que possam prova da primeira dillação de vinte dias e que corressem depois de citados as partes ou seus procuradores, e que todo visto e ouvido pello dito ministro seu requerimento, informado dos termos do mesmo que apresentou e ouvio a dita treplica por oferessida e recebida 
hu inquoantum tanto quanto em direito era recebido segundo a forma da ley, e mandou que esta cousa ficasse em prova de primeira dillação de vinte dias que correria depois de citados oppostos dois procuradores, e logo na dita audienssia citei ao dito procurador dos autores e o sollicitador de causa (fl.25) Jacinto Furtado de Mendonça procurador do reo, por averem de usar testemunhos na dillação asignada de vinte dias de que para constar fis este termo dado por cota reportado elle das audiencias onde possis o que para constar do referido a que me reporto, Manoel de Almeyda Coelho Sampayo escrivão que o escreveis.

Apresentaçam do Rol ao dito

Aos cinco dias do mes de desembro de mil e setecentos e quarenta e nove annos nesta Leal Cidade de Marianna em cazas de morada de mim escrivão abaxo nomeado me foi apresentado o rol de testemunho adiante junto por parte dos autores de que para constar fis este termo de apresentação Manoel de Almeyda Coelho Sampayo escrrivão o escreveis.

(fl.26) Rol dos nomes das testemunhas que ham de produsir os officiaes da Irmandade de São Miguel e Almas na cauza que trazem como Felix Ferreira Jardim

Amaro dos Santos, Joze Coelho de Noronha, Manoel João, Manoel Gomez, Antônio Pereira, Simão Franco Monteiro, Luiz Mendez

Protestão por todas as mais partes que de novo lhe crerem a noticia.

O thizoreiro Domingos Pinto Coelho Penna

Testador da Irmandade João Ferreira Farya

(fl.26v) Aos oito dias do mes de janeyro de mil e setecentos e sincoenta annos, nesta Leal Cidade de Marianna nas posses do concelho della em publica audiencia que as vistas partes e seus procuradores estava fasendo o Doutor João Dias Ladeira por comissão do Doutor Francisco Angello Leytão juis de fora nesta cidade e seu termo o que na dita audiencia pello sollicitador de causa Miguel Peyxoto de Araujo procurador dos autores jas dito a elle dito Doutor juis comissario que nesta causa [assinado] a primeira dellação de vinte dias e requeria a elle dito Doutor juis comissário mandasse e digo comissário lhe asignasse segundo de des dias que correrião citadas as partes ou seus procuradores o que he [?] direyto concedido pelo dito Doutor juis comissario seu requerimento informado dos termos dos autos por mim escrivão asignou nestes autos segunda dillação de des dias e que corressem depois de citadas as partes, aos seus procuradores e logo na dita audiencia [tenhas] ao dito procurador dos autos e ao sollicitador de causas Jacinto Furtado de Mendonça procurador do reo por usarem [?] as 
suas testemunhas na dillação asignada de des dias de que para constar fis este termo tomado por cota na parte como nas audienssias, com ditas posses [?] o que para constar da replica o que me reporto, Manoel de Almeyda Coelho Sampayo escrivão o esceveis.

Replica da audiência em que se lançarão os testemunhos e o reporto [?] na presença de seus procuradores [?] aberto o in[corroído] que se diga ao final definir o Doutor Braz [?].

Aos desenove dias do mes de janeyro de mil e setecentos e sincoenta annos nesta Leal Cidade de Marianna em casas e posses do concelho della em auto li a audienssia em que as vistas partes e seus procuradores estão fasendo o Doutor Francisco Angello Leytão juis de fora nesta cidade e seu Termo e [ley] na dita audienssia pello sollicitador da causa Miguel Peyxoto de Araujo procurador dos autores jas dito ao doutor Paullo de Sousa Magalhães o que com o dito Doutor juis comissario delegou que elle em nome dos seus constituintes so [?] constaria do [próprio] nestes autos requeria fosse o lançado reo, na presença de seu procurador o sollicitador de causas, Jacinto Furtado de Mendonça e que aberta a inquirição se dissesse o final o que tudo visto e ouvido pello dito Doutor juis delegado seu requerimento em forma dos termos dos autos por mim escrivão, ouvio os autores por lançados ao reo presente procurador que consentio no lançamento como [?] a inquirição por aberta ao publico e mandou se dissesse o final de que para constar fis este termo tomado por cota no protocollo das audienssias dos [?] [?] oposses aqui para constar do referido que me reporto, Manoel de Almeyda Coelho Sampayo, escrivão o escrevis.

\section{(fl.27v) Termo de Asentada}

Aos desenove dias do mes de janeyro de mil e setecentos e e sincoenta annos nesta Leal Cidade de Marianna em casas de morada de mim escrivão abaxo nomeado junto a estes autos a inquirição dos autores de que para constar fis este termo de asentada, Manoel de Almeyda Coelho Sampayo escrivão que o escrevis.

(fl.29) A inquirição dos officiaes da Irmandade de São Miguel e Almas, ao reo Felix Ferreira Jardim

\section{Asentada}

Aos nove dias do mes de desembro de mil e setecentos e quarenta e nove annos nesta Leal Cidade de Marianna em casas de morada de mim escrivão abaxo nomeado e onde foi vindo o requeredor do juízo Manoel Dias da Silva Bastos, e por elle e comigo escrivão forão inquiridos e perguntados o testemunho que por parte dos autores nos forão apresentados cujos nomes ditos idades [?] moradas e costumes se alguem de que para constar 
fis este termo de asentada Manoel de Almeyda Coelho Sampayo escrivão que o escrevis.

Luis Mendes morador nesta cidade que vivia do officio de carpinteyro de idade que disse ser de cincoenta annos pouco mais ou menos testemunha o que o dito inquiridor deferio Juramento dos Santos [Evangellos] em hum juiso de fee em que pos sua mão direyta sob cargo de quoal lhe encarregou jurasse a verdade de que soubesse a elle fosse perguntado e recebido [?] por elle dito o juramento asim e prometeu faser dos costumes [?] disse nada. E perguntado elle testemunho pello (fl.29v) conhecido [?] no primeyro artigo na contrariedade dos autores [?].

E do segundo disse que por elle testemunho dis oficial de carapina e arebathar na obra de que se trata ser [?] no o que Ihe pagava o embargamento presenciou fallase entre o embargamento e Joze Coelho mestre entalhador que com o retiro que se trata ficava a mesma obra mais gallantaria e ouviu diser o mesmo embargante por muitas veses que na dita forma o havia de faser, indo que fica prejudicado e mais não disse desta.

E o terceiro disse que no mesmo tempo indo a dita obra Domingos Pinto Coelho Penna Ihe deu o embargante parte de que determinava o faser, e que asim ficava a obra muinto melhor ao que respondeu se asim esse [?] o fisesse e que se topassem mais algua cousa não duvidava [?] no que o colorião não Ihe lembra estivesse mais do que Antônio Pereyra Simão Franco e Joze Coelho e mais não disse deste e nem do quarto.

E do quinto disse que ouviu diser a Manoel da Silva mestre pedreyro que o embargante lhe dera a diressão e risco para faser o arco e mais não disse desta e nem do sesto.

E do setimo disse que sabe pello [cies] depois do embargante ter dado (fl.30) principio a obra de que se trata, trabalhou sem ter com os officiaes s[?]em o retabollo da Capella de Santo Antônio da mesma Ssé, o quoal fes elle nesta muinto pouco tambem andou fasendo hua obra no posso do Excellentissimo e Reverendissimo Bispo, e por as ditas duas obras se [vistou] das madeiras que tinha em casa saberia herão para a obra de que se trata inormes no tempo por elle testemunha ter huas rasões com o mesmo embargante e despedio o mesmo do ser servisso disendo que não queria que trabalhasse na dita obra, mas no tal tempo ainda não soltarão [?] madeyras, e ao depois ouviu diser a Antonio Pereyra que tambem o embargante o despedira por outras rasoens que Amaro dos Santos mestre entalhador se fora embora por causa de não ter aviamentos pertencentes ao seu ofício de entalhador e mais não disse deste e nem do outavo nono e dessimo por ser de direito ultimo da contrariedade que todos digo da contrariedade.

Tréplica

E perguntado elle testemunha pello conhecido [?] no primeiro artigo elle disse que quando elle testemunha ouvio fallar entre e embargante e Joze 
Coelho sobre a obra do retiro foi ao depois do mesmo embargante ter vindo nessa (fl.30v), no que ao foi contar madeiras para a dita obra não sabe o que antes disse, se falasse na tal inovação, e mais não disse desta.

E do segundo disse que muintos certa [?] ouvio diser ao embargante que indo que elle perdesse o que perdesse, tinha gasto grande em que a tal obra que andava fasendo, ficasse melhor que a do retabollo de Nossa Senhora do Rozario, e mais não disse desta.

E do terceiro disse, que ouvio diser ao mesmo embargante, que os embargados Ihe davão mais dusentas outavas de ouro pella dita obra pois havia quem the fisesse menos dellas, e mais não disse deste e nem do quarto. E do quinto disse, que tem ouvido diser a muintas pessoas que o embargante ainda não principiou a obra que acabasse e ouvio diser o Joze Coellho e o Manoel João, que trabalharão com o embargante em Santa Barbara que elle lá se tratara com outro nome de notorio que se retirou fugitivo desta cidade e mais não disse deste e nem do seisto.

E do setimo disse, que logo no principio quando elle testemunha foi trabaIhar para dita obra tem de noticia que o embargante não satisfaria o quam o servio e que em Santa Bárbara fisera [?] outro nome fallou ao thisoureiro da Irmandade Domingos Pinto Coelho Penna, junto com outros (fl.31) officiaes e elles disserão que não continuarião na dita obra sem que elle se the obrigasse a pagar o que ganhassem, o que fes e pagou a elle testemunha sem ouvido diser que tambem tem [?] pago aos mais, e mais não disse deste e nem do outavo por ser de direito ultimo da treplica que todos the forão lidos e decorados pelo dito inquiridor com quem asinou, Manoel de Almeyda Coelho Sampayo escrivão o escreveis.

Luis Mendez

Joze Coelho de Noronha morador em Villa Rica que vive da sua ocupação de entalhador de idade que disse ter de quarenta e sinco annos pouco mais ou menos testemunha aqui no dito inquiridor deferio o Juramento dos Santos aos Evangelhos em hum juiso delle em por sua mão direita sob o cargo do quoal the encarregou jurasse em verdade do que soubesse se elle fosse perguntado e recebido por elle o dito juramento asim prometeu fazer dos costumes disse nada.

E perguntado elle testemunha pello conhecido no primeiro artigo da contrariedade e autores do seu modo.

E do segundo disse que elle testemunha andou trabalhando na obra de que se trata por oficial de entalhador (fl.31v) junto com o embargante e vendo elle testemunha que o Mendonça do Retiro que se trata hera mais conveniente que ficava a obra com mais perfeição, o comunicou o embargante prejuiso algum, em rasão de que suposto levasse digo em rasão que levava menos ressaltos, e menos does pillares, e as collunas havião de ser feitas de todas as [fossas] e indo estas em caixas, se coitou o trabalho para o embargante só duvidou o embargante em seis molduras tortas que 
só estavão principiadas a este trabalho disse o tisoureiro Domingos Pinto Coelho Penna que asim diria por ficarem as ditas molduras [frustradas] com o dito Mendonça e mais não disse deste.

E do terceiro disse que na presença delle testemunha falou por muintas veses o embargante ao thesoureiro Domingos Pinto Coelho Penna no dito Mendonça e o quoanto elle hera conveniente e o indo que alegavão prejuisos se ele [?] se guiou [?] hera ignorancia nelle e elle testemunhadas prossedia fasello [tombo] com as rasoens que so declarou no que elle convinha e mais não disse deste digo no que elle convinha, ainda que (fl.32) por veres que estava se tratando e mais não disse nada deste nem do quarto por ter dito de sua materia.

E do quinto disse que sabe pello ver que o embargante deu a direção e riscou o lugar para se faser aos com [?] que onde se rompeu o [saypo] da parede [seo] paravento do dito retabolo e mais não disse deste, nem do seisto por ter dito.

E do setimo disse que sabe pello ver o embargante depois que ajustou a obra de que se trata tambem ajustou o retabolo de Santo Antônio no quoal elle testemunha trabalhou e pouco Ihe falta para estar acabado e ouvio diser depois que sabia [?] de sua companhia que tambem sustara uma capellinha em casa e posse do Excelentíssimo e Reverendíssimo Bispo, e vindo elle testemunha depois que o mudou para Villa Rica esta cidade e posse onde ou indo ao mesmo passo, vio estar o emabargante trabalhando na dita obra junto com os seus officiaes e gastou na dita obra do retabollo de Santo Antônio por todas madeiras que o embargado Domingo Pinto Coelho Penna tinha comprado para a obra de que se trata para saber a importancia na quantia que Ihe havia dados [?] e tambem Ihe disserão os officiaes que trabalhavão com o embargante (fl.32v) que este gastara na obra na posse do Excellentíssimo e Reverendíssimo bispo quoais todas as madeiras que tinha para a dita obra, e por elle testemunha ter suas duvidas com o embargante e despedio o mesmo, e não por falta de madeiras porque no tal tempo ainda as havia e outros officiaes por dispostos que tiverão com o mesmo se terão tambem em obra e mais não disse deste e nem do outavo. E do nono que elle testemunha vio na mão de Domingos Pinto Coelho Penna recibos do embargante e de outras pessoas a quem o dito Domingos Pinto pagoa pelle dito embargante a importância [?] de setecentas e tantas outavas porem a dita obra mayor por parte della está feita e mais não disse deste nem do dessimo ultimo da contrariedade.

\section{Tréplica}

E perguntado elle testemunha pello contheudo no primeiro artigo delle disse que antes do embargante vira [?] huma possa [?] o procure faser madeiras que lhe faltavão para a dita obra comunicou elle testemunha com o embargante a mudança que se trata no que elle [conveyo] [?] e que onde chegou 
só elle testemunha tinha feito a planta para o dito retiro e que o lhe mostrou e não [?] vio que os embargados falassem ao embargante na tal mudança pois elle testemunha foi o que lhe comunicou e o mesmo deu (fl.33) parte disse ao dito Domingos Pinto, e mais não disse deste.

E do segundo disse, que asim que ella testemunha foi para a obra de que se trata logo o embargante the disse por varias veses que tinha empenho grande em que a dita obra ficasse melhor do que a de Nossa Senhora do Rosário, e mais não disse desta por ter dito.

E do terceiro disse que a elle testemunha disse o embargante que havia quem fisesse a dita obra por menos dusentos outavas do que elle o ajustou e mais não disse deste, nem do quarto por ter dito de sua materia.

E do quinto disse, que ouvio diser varias pessoas do Rio das Mortes que o embargante ajustara hua obra naquele termo e que sem a acabar fugira e estando elle testemunha fasendo hum retabollo na Freguesia de Santa Bárbara, la foi o emabargante ter com elle testemunha pedirlhe que the dasse o que foras o que elle testemunha fes, porem como comesou a ter duvidas com todos os oficiaes, elle testemunha o expulssou e se tratava na dita Santa Bárbara com o nome de Joze da Silva Pinto, e sem outros defeitos acha [?] notorio que desta cidade se retirou fugitivamente, e mais não disse desta nem do seisto.

E do setimo disse, que asim que elle testemunha ajustou com o embargante e vir trabalhar para a dita obra logo foi fallar ao embargante (fl.33v) Domingos Pinto e lhe disse o negocio que tinha feito com o embargante, porem que não vinha para a dita obra sem que elle lhe obrigasse a pagar o que elle fes e o mesmo procedeu tambem com dois oficiaes mais que tambem conhessião o embargante de Santa Barbara, e a todos tem pago, e tambem se obrigou mais dois na presença delle testemunha e mais não disse deste nem do outavo por ser de direito e como da treplica que todos forão lidos e declarados pello dito inquiridor com que asignou Manoel de Almeyda Coelho Sampayo escrivão que o escreveis.

Joze Coelho de Noronha

Asentada

Aos dezesete dias do mes de janeiro de mil e setecentos e sincoenta annos nesta Leal Cidade de Marianna em cazas de morada de mim escrivão abaxo nomeado com com la [?] foi vindo o inquiridor do juiso Manoel Dias da Silva Basto e por elle comigo [?] escrivão forão inquiridos e perguntados os testemunhos que por parte dos autores embargados não forão apresentados cujo nomes e segundo que fis este termo Manoel de Almeyda Coelho Sampayo que o escreveis.

Amaro dos Santos, morador em Villa (fl.34) Rica que vive de entalhador de idade que disse ser de quarenta e hum annos pouco mais ou menos 
testemunha a quem o dito inquiridor deferio o Juramento dos Santos Evangelhos em hum juiso delle em que pos sua mão direita sob cargo do quoal Ihe encarregou jurasse a verdade de que soubesse elle fosse perguntado e recebido por elle o dito juramento asim o prometeu fazer dos costumes disse nada.

E perguntado elle testemunha pello contheudo no primeiro artigo do libello dos autores disse na contrariedade segundo disse que elle testemunha tambem andou trabalhando na obra de que se trata depois de elle ter dado principio o embargante, e em hua ocasião presenciou diser a este Joze Coelho, que tambem trabalhava na dita obra de prerito no oficcio de entalhador, que fasendo na dita obra de que se trata ficava elle com mais galantaria [?] e perfeição e que da factura delle senão seguia prejuiso algum o embargante ao que pos [?] por deu este que se asim hera se fisesse pois com effeito este não entendia do dito officio porem elle testemunha tambem entende que pouco prejuiso ou nenhum, podia ter o embargante com esta enovação em razão de que a talha era a mesma, e so os pillares havião de ser mais longos (fl.34v) porem em reconpença deste exceso, ficava mais dois pillares pequenos que havião de [tirarse] da renda, e mais não disse deste nem do terceiro nem do quarto por ter dito, nem do quinto e sesto e nem dos mais athe o final do libello digo final da contrariedade.

\section{Treplica}

E perguntado elle testemunha pello contheudo no primeiro artigo della disse que quando elle testemunha ouvio concurssar o embargante com Joze Coelho, aveste com elle o respeito que declarou no segundo digo da contrariedade fes antes do embargante vir parar a posse [?] e que onde veyo tinha o dito Joze Coelho feito a planta e no quoal elle consentio, pois sempre lhe devia que fisesse a elle o que entendesse e mais não disse deste. E do segundo disse, que estando elle testemunha ainda em Villa Rica antes de vir trabalhar para a obra de que se trata lhe disse Joze Coelho que o embargante the dera ordem para elle faser o que entedesse, pois tinha o empenho em que a tal obra fasia milhor que a do altar de Nossa Senhora do Rosario, e ao depois muintas veses ouvio diser o mesmo embargante que tinha empenho em que a tal obra desbancasse [?] a de Nossa Senhora do Rosario, e mais não disse deste e nem do terceiro e nem do quarto.

(fl.35) E do quinto disse elle testemunha só tem conhecimento do embargante do Arrayal de Santa Barbara onde elle testemunha andava trabalhando com Joze Coelho tambem no dito arrayal trabalhava o embargante em huns coxilhos que tomou de emprestado ao dito Joze Coelho e por rasoens que teria com elle nos lidos [?] do mesmo embargante se foi embora sem acabar a dita obra pello dito Joze Coelho a despedir no quoal arrayal, se tratava e embargante com o nome de Joze da Silva Pinto e vindo para esta cidade o achou com o nome de Felix Ferreira Jardim sem noticia pello ouvir diser 
outros [?] officiaes que trabalharão com elle no Rio de Janeiro e Rio das Mortes que la tambem se tratava por Felix Ferreira Jardim, e he notorio que se retirou desta cidade de fugitivo, e mais não disse deste.

E do setimo disse, que elle testemunha e o hum seu camarada fallou Joze Coelho, parou sem [?] trabalhar na obra de que se trata e disendo lhe que vimos que hera necessario ver quem se achava obrigar a pagar pois senão fiavão o embargante e elle o respondeu que nem malesiava nella mas que so fallara o Domingos Pinto Coelho Penna e que so Ihe obrigara a proporIhes tambem que elles a quem elle falasse, e contestasse nessa (fl.35v) conformidade veio trabalhar para a dita obra, e elle tem pago Domingos Pinto parte [?] o dis que lhe ha de pagar o resto, e mais não disse deste e nem do outavo que he de direito ultimo da treplica que todos Ihe forão lidos e declarados pello dito inquiridor com que não ignorou [?] Manoel de Almeyda Coelho Sampayo escrivão o escreveis.

Amaro dos Santos

Simão Franco Monteiro morador nesta cidade que vive do oficio de carapina de idade que disse ser de vinte e quatro annos pouco mais ou menos testemunha a quem o dito inquiridor deferio o Juramento dos Santos Evangelhos em hum juiso delles em que pos sua mão direita sob cargo do quoal the encarregou jurasse em verdade do que soubesse se elle fosse perguntado e recebido por elle o dito juramento asim prometeu fazer dos costumes disse nada.

E perguntado elle testemunha pello contheudo no primeiro artigo da contrariedade dos autores disse nada.

E do segundo disse, que elle testemunha tambem trabalhou algum tempo na obra de que se trata alego [?] do embargante, e em hum ocasião presenciou diser Joze Coelho, que tambem trabalhava na dita obra, e hera perito no dito oficio, ao embargante na presença de outras pessoas que the não lembra quem forão, que a tal obra ficava melhor com o retiro de que se trata, e que elle não seguia o [pedreiro], no que consentio o embargante nos diria que queria o que elle disse mais alguma cousa pois the havia de levar mais tempo e mais madeiras e nisto andarão fallando em hum pouco de dias, o the que sobre isto tiverão humas rasoens as que aos e como diria dito Domingos Pinto Ihe disse na presença de elle testemunha que se lhe não fasia consta faser o dito retiro e não ficasse pois não the dava mais cousa algua e no entender delle testemunha lhe paressa que a tal obra não hera mais custosa que aquela que o primeiro se tinha terminado e mais não disse deste.

E do terceiro disse que em uma ocasião estando digo ocasião antes de principiado a obra de que se trata ouvio elle testemunha diser a Domingos Pinto que o embargante fora a sua casa, e elle pedira a lhe disse algua cousa pello dito Mendonça mas que elle lhe respondera Ihe não dava mais nada e mais não disse deste e nem do quarto. 
E do quinto disse, que sabe pello que vio, que o embargante riscou o caso [?] para se faser ao cem [?] vistas veses hum vaso que faria o pedreyro nelle e mais não disse deste e nem do (fl.36v) seisto.

E do setimo disse, que sabe pello ver que depois do embargante e seus oficiais andarem trabalhando digo que depois do embargante ter feito a obra que se trata com os embargados e ajustou a factura de hum retabollo de Santo Antônio em Antônio Pereira dos Santos, pois elle testemunha presenciou este ajuste e tinha visto antes e certamente [?] as obrigaçõens e riscos asignados pellos embargados porem não acabou a dita obra e ainda hoje se acha por acabar e fui publico que tambem o ajustava outro retabollo pequeno em casas e posse do Excellentíssimo [deshado], na obra que elle testemunha andou trabalhando, com hua casa fes alguas obras de pouca intidade e sabe pello ver que para a dita obra do senhor Bispo deu elle o embargante de alguas madeiras que estavão [coletadas] para a dita obra que se trata, mas não se valleu dellas para a dita obra de Santo Antônio porque para esta vierão só decretadas [?], Donato sabe pello ver, que o reo despedio alguns oficiaes da dita obra mas não sabe a causa e mais não disse deste nem do outavo nem do nono nem do dessimo por ser do direito ultimo da contrariedade.

\section{Treplica}

E perguntado elle testemunha, (fl.37) pello contheudo do primeiro artigo delle não disse nada.

E do segundo disse, que muintas veses ouvio diser ao embargante que tinha empenho em que a tal obra ficasse melhor do que a do Rosario e mais não disse deste.

E do terceiro disse, que elle testemunha vio hua obrigação de hum ajuste que fiserão Marcellino de Miranda, Joze de Oliveira e Antônio Pereira com os embargados e se obrigavão o que vai o fazer a dita obra por novecentas outavas fora a condução das madeiras, o quoal condução e [costamento] das madeiras correu por conta do embargante e por isso the derão mais as dusentas outavas e mais não disse deste e no do quarto.

E do quinto disse que ouvio diser a pessoas de que se não lembra que o embargante tinha principiado em varias partes alguas obras as quoaes não acabara que della se retirara fugitivamente e ouvio diser a Joze Coelho que em outras partes se tratava com o nome diverso do que tinha de notorio que se retirou desta cidade fugitivamente e mais não disse deste e nem do seisto. E do setimo disse que a elle testemunha (fl.37v) fallava o embargante para trabalhar na obra de que se trata e elle testemunha antes de antes de para elle vir fallava Domingos Pinto lhe perguntou se elle havia de pagar, pois desconfiava do embargante que o lhe prometeu pagar e com effeito pagou a ella testemunha pois se algua cousa lhe resta he por elle the não pedir e mais não disse deste nem do outavo por ser de direito ultimo da Treplica que 
todos the forão lidos e decorados pello dito inquiridor com quem asignou Manoel de Almeyda Coelho Sampayo escrivão que o escreveis.

Simão Franco Monteiro

Termo de Vista

Aos desenove dias do mes de janeiro de mil e setecentos e sincoenta annos nesta Leal Cidade de Marianna em casas de morada de mim escrivão abaxo nomeado continuo visto destes autos ao Doutor João da Costa Maya procurador do reo embargante de que para constar fis este Termo de Vista Manoel de Almeyda Coelho Sampayo escrivão que o escreveis.

(fl.40) Termo de Conclusam ${ }^{25}$

Aos dose dias do mês de fevereiro de mil e setecentos e sincoenta annos nesta Leal Cidade de Marianna em cazas de morada de mim escrivão abaxo nomeado, faço estes autos de conclusos e o Doutor Francisco Angello Leytão juis de fora nesta cidade e seu Termo, de que para constar fis este de conclusão Manoel de Almeyda Coelho Sampayo escrivão o escreveis. Visto [?] com $3 / 4$ e 2 oitavas [?]

Vistos estes autos e embargos recebidos, contrariedade, replica e treplica com mais que della consta. E como o embargante não foi prova algua sobre a manobra [?] articulada nos seus embargos, he a mesma (fl.40v) inatendivel, e sem valor em direito para [illi] [?] dis a acção e muito menos, achandose a mesma acção legalmente provada pela inquiriçam dos embargados em que se faz dentro que a inovação da obra a que o embargante recorreo não procedeo de algú novo ajuste que fisesse com os embargados, mas sim da sua propria eleição tomandoa sobre si, sem outra algua convenção, em cujos [?] nos fica prevalecendo a obrigação folha 2 independente de outra condição, e a elle o embargante a direito a darlhe inteiro cumprimento. Pelo que sem embargo dos embargantes que julgo não provados, julgo a nothificação folha 2 por inicio e mandose cumpra como nella se conthem, e pague the [?] as causas mesmas. 14 de fevereiro de 1750.

Francisco Angello Leytão

\section{Publicação}

Aos deseseis dias do mes de fevereiro de mil e setecentos e sincoenta annos nesta Leal Cidade de Marianna em cazas de morada de mim escrivão abaxo nomeado digo em cazas de posse do concelho della em publica audienssia que os vistos e partes e seus procuradores estava fasendo o

25 Na certeza de que não causarão prejuízos no entendimento do documento, foram suprimidas dessa transcrição as folhas $12,12 \mathrm{v}, 38,38 \mathrm{v}, 39$ e $39 \mathrm{v}$. 
Doutor João Dias Ladeira por comissão do Doutor Francisco Angello Leytão juis de fora nesta cidade e seu termo e he na dita audienssia pelo dito doutor juis (fl.41) comissário foi publicada a sentenssa essa que mandou se cumprisse e goardasse como nella se constam e declaro de que para constar fis este termo de publicação Manoel de Almeyda Coelho Sampayo escrivão o escreveis. 